\title{
The Rhetoric of Agitation and Control Confronts Movement Theory and Practice
}

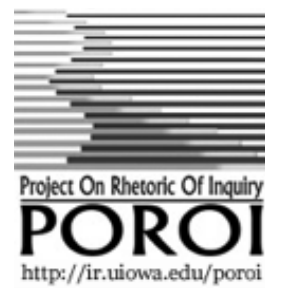

\section{Bruce E. Gronbeck}

Professor Emeritus, Department of Communications, University of Iowa Iowa City, IA USA

Poroi 9,2 (August 2013)

Unlike the others in this collection of articles, I was Don Ochs' classmate for three years. When taking classes in classical rhetorical theory or practice, he tended to share instructional tasks with the professor-ofrecord. His classical education was exemplary. He had drunk deeply of the Greco-Roman brew. He was a man whom you could ask, "So what are you doing at 2:34 p.m. tomorrow?" and get a precise reply-the most totally organized doctoral student I've ever met (so unlike the rest of us).

By the time that he had left Iowa with his Ph.D. and then returned to the faculty, and by the time that he and John Waite Bowers had taught their movements class and written their book, I was long gone to my job at the University of Michigan. I taught my first graduate seminar on social movements in the fall of 1969 , back when we still talked about the women's liberation movement as exercises in public bra-burning. In my first or second year of teaching that class, however, Bowers and Ochs provided me with a pre-publication, dittoed copy of the text. I learned how to teach that seminar from those purple pages.

And that fall is where I'll begin this far too brief review of the literature on social movements relevant to Bowers and Ochs' book (1971). I'll commence with that late ' 60 s period, following the arc of some of the directions movement studies flowed across the decades, and finish by explaining how and why, amazingly perhaps, the third edition of the book is still relevant to today's popular agitation.

\section{Born in the Late ' $60 \mathrm{~s}$}

Bowers and Ochs ${ }^{1}$ were writing their book amidst the blossoming of exciting rhetoric-relevant literature on social movement studies. The signal cannon that first fired scholars' imaginations about this kind of work appeared in Leland Griffin's dissertation (1949), article (1952), and then book chapter (1958) on the rhetoric of "historical movements." $\mathrm{He}$ set up a dialectical pattern for analyses of pro- and anti-groups in mortal combat as opposing warriors. He laid out a traditional three-stage model

\footnotetext{
${ }^{1}$ I will refer to "Bowers and Ochs" as the authorial team even though there are now four authors for the current edition. I'm doing so because I'm essentially following the impact of that first edition on the field. I certainly appreciate the contributions of the other two authors.
} 
of rhetorical battle-in his case, periods of inception, rhetorical crisis, and consummation. As Lucaites, Condit, and Caudill (1999) have noted, he never really defined "movement," that is, defined what it is that "moves," except of course time.

The initial pattern for the rhetorical studies of social-political movements thus was set in this way. Robert Cathcart $(1972,87)$ formalized the dialectical model when arguing that movements are distinguished from other kinds of rhetorical events through reciprocal acts offered up by movements and the established order, what he called " $a$ dialectical enjoinment in the moral arena." Scholars such as Herbert Simons (1970), Robert Scott and Donald Smith (1969), Robert Scott and Wayne Brockriede (1969), and Arthur Smith [now Molefi Asante] (1969) worked in the same way. Movements came to be understood as confrontations between an institutionalized entity and (usually) a noninstitutionalized attacking and de-stabilizing social-political force.

The three-stage model-essentially a model of beginnings, middles, and endings-was popular. Eric Hoffer in his famous The True Believer (1951) argued that what he termed "mass movements" needed "men of words" to generate public notice, "men of action" to exert physical and symbolic forces on the targets, and then "men of words" once more to bring them to a successful close. Gronbeck (1972) outlined the different rhetorical functions played by movement discourses across the three phases, and Griffin himself (1952) had suggested the different kinds of content needed to keep the movement working forward.

And then there was the question, "What moves?" in social-political confrontations. Griffin (1952) never really got beyond noting that the passing of time produced different events that might be relevant to movement strategy and discursive effectiveness. Gronbeck (1972) discussed "force fields"-social-psychological, political-institutional, and philosophical-ideological forces-that affected how the University of Michigan and the Black Action Movement on its campuses affected the ways that the principal actors disputed with each other in different stages.

But the major player in this discussion became Michael Calvin McGee (1980, 1983), who in special issues of the journal Communication Studies very persuasively argued that what "moves" in social-political movements are $(1983,76)$ "states of mind people are in when they fool themselves into believing that they are part of a 'movement." States of consciousness, not material bodies, are what become re-formed when movements have their social-political effects. Simons (1970) had urged that movement leaders had to manage the physical resources available to the group to succeed; McGee said, no, what must be managed are beliefs, attitudes, values, and especially self-identities.

All in all, Bowers and Ochs's book was almost perfectly adapted to prevailing conceptions of social movements and contemporary understandings of rhetorical confrontations. They grounded their analysis of social change within prevailing theories of social organization, French and Raven's (1953/1960) enduring taxonomy of the bases of social power, rumor studies in order to talk about changes in message characteristics as they flow through social organizations, and, most 
characteristically, their own assemblage of progressively more forceful rhetorical strategies for agitation:

- petition

- promulgation

- solidification

- polarization

- nonviolent resistance

- escalation/confrontation

- Gandhi and guerrilla

- revolution

as well as progressively more forceful strategies for control:

- avoidance

- suppression

- adjustment

- capitulation

Within each of these strategies, there were habitual tactics to be employed in pursuit of them.

What made Bowers and Ochs's approach to rhetorical strategies and tactics so very useful was that their progressivist theory of communicative instrumental and symbolic behaviors was not predictive, ${ }^{2}$ but rather based on a conception of communication competence. Dell Hymes (1962) had reshaped Noam Chomsky's version of that idea in his taxonomies of "the ethnography of speaking." Bowers and Ochs, however, pioneered a rhetorical understanding of that idea, that is, of arguing that communication competence reflected significant leveraging of socialpolitical power in practical communication situations. Competent agitators generally move through the strategies from the least to the more and more disruptive; likewise, agents of control try avoidance before suppression, etc. With communication competence or sophistication conceived of as a rhetorical standard, even movements that seemingly "failed" nonetheless could be adjudged rhetorically sophisticated and strategically sound-and hence sources of lessons worth emphasizing.

\footnotetext{
${ }^{2}$ Actually, in the final chapter of the book, Bowers and Ochs (1971) laid out a figure ("Encounters between agitation and control") to chart predictions of outcomes in the clash-what they called the interface. Using three bilateral characteristics agitating peoples might have (high/low membership, high/low potential membership, and high/low sophistication) and three possible characteristics of control groups (high/low power, strong/weak ideology, and high/low sophistication), they attempted predictions of outcomes. Notice that both agitation and control draw strength from "sophistication"-what I'm calling competence. That idea is key to the whole book, its progressive arrangement of strategies as well as its predictive generalizations.
} 
The Rhetoric of Agitation and Control (1971) was in many ways a practical-conceptual summary of what had been learned about socialpolitical movements or popular-institutional confrontations up to that point in the twentieth century.

\section{New Paradigms for Consciousness Theories of Movements}

As the '70s unfolded, as revolutionary fever calmed, and as different sorts of reform or even revolutionary forces came into play in societies around the world, the dialectical paradigm of agitation and resistance underwent adjustment, even radical retheorizing. Let me point to only three of the new paradigms that took on the patina of "post-"6os thinking" in this arena of thought. First, a bundle of three consciousness theories that floated through the $20^{\text {th }}$ century.

Perhaps the most famous of the psychological theories of extreme behavior was articulated in the late nineteenth century by Gustave Le Bon (1895/1896). His theory of mob psychology-that collective riotous behavior created mind-sets that were more extreme than those held by any individual in the mob-was highly popular. Crane Brinton (1938/1965) produced historical research on the English, American, French, and Russian revolutions that affirmed Le Bon's theory, though he preferred to talk about states of fever that would strike a collectivity, running its course through periods of violence until it dissipated and the country could return to conditions of moderation and quiescence. Today, perhaps the greatest French sociologist of social movements, Alain Touraine, has done close textual studies of the self-conceptions or worldviews of what he calls "social actors" in their relationships to others in of their perceptions of their environments. The book of his that I own, Return of the Actor: Social Theory in Postindustrial Society (1984/1988), examines the shifts in industrial actor' interrelations in Italy from the labor-organizing "red years" of 1919-20 to the fascist "black years" of 1921-22. He traces the altered interpersonal relations among individuals in close textual analyses of newspapers that abetted such a radical cultural shift.

In all, such consciousness studies take seriously Bowers and Ochs' understanding of communication as instrumental, symbolic behavior guided by an emphasis on individual and collective consciousness as the locus for social-political change.

Even more popular in rhetorical and communication studies are works treating image events or media campaigns. Kevin DeLuca (1999) has been one of the principal architects of this paradigm in his research on "image events" that are staged to gain significant attention from especially the television press and Internet devotees in various countries. If confrontational dramas are played out before cameras, they are accorded significance and cultural importance by viewers in their very specularity and "newsworthiness." There are not always clearly defined "agitators" and "control" groups - think of the diffused segments and their variegated goals that comprised the Occupy movement and, for that 
matter, the range of institutions that occupiers demeaned as enemies of the $99 \%$.

Such splintering or diffusion of both agitating and controlling groups is visible in two of the chapters added to the third edition of Bowers and Ochs (1971/1993/2010): one on the anti-WTO "Battle in Seattle" of 1999 and the other on the protest of some 14 million people across the world on 15 February 2003 against the upcoming invasion of Iraq by the U.S. and its "coalition of the willing." Because of the differences and even dissociations between and among those comprising both agitation and control in those situations, there were no coordinated strategies or common tactics of attack and defense, negotiations between competing entities was fragmented, and victory or defeat was impossible to define.

Image events making up media campaigns for social-political-havoc raise havoc with our understanding of what constitutes "communication competence" in such diffused public performances. There usually is no central leadership or command structure. Established institutions cannot focus their attention on official spokespersons, for there are none. Whose competence should be challenged? That can be impossible to know.

Let me mention a third kind of study coming into prominence in the twenty-first century: work on the roles of the new social media in socialpolitical change. Social media played highly significant parts in the series of WTO protests from Seattle to Genoa to Quebec City to Salzburg and beyond. Even more impressive was the assemblage of worldwide antiinvasion of Iraq marches in 2003. The coordination of so many people in so many national capitals around the world would have been impossible without a cheap and efficient communication technology.

But we are discovering that the social media can do much, much more than work as telephones. They've become the eyes and ears even of the mainstream media. The new "two-step flow" of media information and opinion is no longer a flow from one person to another, but rather, from Internet-embedded or smart-phone transmitted audio/video feeds to a licensed radio or television operation. The small portable camera or phone can transit in places where the mainstream networks do not have access or permission to set up. Private individuals transmit photos and streaming video that permit secret, hidden suppression of and assault upon protesting citizens to be made fully public. Fact-checking can be carried out by people on the ground almost immediately after reported events. Instantaneous news can be gathered even without broadcast media's uplinks.

Social movements have been transformed by their use of new technologies, and the public's access to agitation from around the world has been revolutionized by the digital connections now possible between local and global communication systems.

\section{A Third Edition in a Changing World}

Even the face of the new paradigms coming out of consciousness studies, media studies, and the digital revolution, The Rhetoric of Agitation and Control appeared in a third edition in 2010 in time for its fortieth 
anniversary. Why? Obviously, the owners and editors of Waveland Press recognized something in the book's quality and its relevance to rhetorical and communication studies of the twenty-first century. Anyone reading it can sense the quality of its conception, writing, and direct relationships between its theoretical framing and the usefulness of that framing in directing scholars' attention to signal actions in practical social-political controversies. But why else?

I suggest that countries around the world have witnessed a robust rebirth of social-political dialecticalism. While not always quite on the scale of the revolutions that Brinton (1938/1965) wrote about, agitation in recent times often erupts quickly, massively, and excitedly, as in a feverish drive for radical change. We are not celebrating a return of the '6os culture, but of aspects of agitational forms that are now operative within today's environments.

Students of the New Right movements in the U.S.-think about the Moral Majority, the Neocons of the Reagan revolutions, the post-1994 Gingrich legislative blueprint with its amalgamation of religious and political conservatism, and the Tea Partyism of the last three years-have witnessed dialectical confrontations between existing religious, political, and governmental institutions and what we now identify as "value-based" cultural groups seeking power and institutional leverage. The hot-pink value issues-abortion, same-sex marriage, gun control, death penaltyare perennially on social-political agenda somewhere in this land every year. They thrive on two-valued logics that allow for no compromise but for this very reason heighten their attractiveness as image events for the news camera. They're still living off the dialectical model of agitation and control.

Not only the right has kept dialecticalism alive. We've already noted leftist backlash movements from around the world. The post-9/11 antiwar movements, the Occupy movements both in the U.S. and elsewhere, and certainly the democratic populism at work in conservative Muslim, Arab, and African countries leading to the Arab spring and larger African revolutions are relevant instances of left-leaning protests and loud shouts for broad social-political-governmental turnover. Less bloody but equally disruptive are election-based changes-of-government recently in France and Italy, with economically conservative governments tossed out in favor of liberal agenda proposing comparatively radical change in the Euro Zone, even jingoistic cries to return to nativist currencies. Those elections, too, went forward riding on strongly dialectical arguments that framed the contests.

The chapters that the newest author of this book, David Schulz, has added to the third edition recognize and begin to incorporate some of these post-'6os paradigms for movement studies. As yet, the blending of the consciousness, image event, and social media paradigms with the competency model for assessing dialectical agitational performances and force is not smoothly done, but it's coming along nicely. As any good student of social movement knows, adaptation is a key to success not only for movements and those who would resist them, but for the scholar who is working to comprehend the conditions that spawn them, the 
happenings that ignite them, the force-vectors that propel them, and the wise people of words who return societies to conditions of stability and quietude following their runs.

May The Rhetoric of Agitation and Control help new cohorts of students and their mentors to pursue these tasks for another forty years.

\section{References}

Bowers, J.W., and Ochs, D.J. 1971. The rhetoric of agitation and control. Reading, MA: Addison-Wesley Pub Co.

Bowers, J.W., Ochs, D.J., Jensen, R.J., and Schulz D.P. 1971/1993/2010. The rhetoric of agitation and control. Third ed. Long Grove, IL: Waveland Press.

Brinton, C. 1938/1965. The anatomy of revolution. Rev. ed. New York: Vintage Books.

Cathcart, R.S. 1972. New approaches to the study of movements: Defining movements rhetorically. Western Journal of Communication, 36:2, 82-88.

DeLuca, K.M. 1999. Image politics: The new rhetoric of environmental activism. New York: Guilford Press.

French, J.R.P., and Raven, B. 1953/1960. The bases of social power. In D. Cartwright and A. Zander, eds., Group dynamics (pp. 259-69). $2^{\text {nd }}$ ed. New York: Harper \& Row.

Griffin, L. 1949. The anti-masonic persuasion: A study of public address in the American anti-masonic movement. Ph.D. diss., Cornell University.

---. 1952. The rhetoric of historical movements. Quarterly Journal of Speech, 38:2, 184-8.

---. 1958. The rhetorical structure of the antimasonic movement. In D.C. Bryant, ed., The rhetorical idiom (pp. 145-59). Ithaca, NY: Cornell University Press.

Gronbeck, B.E. 1973. The rhetoric of social-institutional change: Black action at Michigan. In G.P. Mohrmann, C. Stewart, and D.J. Ochs eds., Explorations in rhetorical criticism (pp. 96-113). University Park, PA: Pennsylvania State University.

Hoffer, E. 1951. The true believer: Thoughts on the nature of mass movements. New York: Harper \& Bros.

Hymes, D.H. 1962. The ethnography of speaking. In T. Gladwin and W.C. Sturtevant, eds., Anthropology and human behavior. Washington, DC: Anthropology Society of Washington.

Le Bon, G. 1895/1896. The crowd: A study of the popular mind. Trans., Anon. London: T. Fisher Unwin.

Lucaites, J.L., Condit, C.M., and Caudill, S. 1999. Contemporary rhetorical theory: A reader. New York: Guilford Press. 
McGee, M.C. 1980. Social movement: Phenomenon or meaning? Communication Studies, 31:1, 233-44.

---. 1983. Social movements as meaning. Communication Studies, 31:1, 74-77.

Scott, R.L., and Smith, D.K. 1969. The rhetoric of confrontation. Quarterly Journal of Speech, 55:1, 1-8.

Scott, R.L., and W. Brockriede, eds. 1969. The rhetoric of Black power. New York: Harper \& Row.

Simons, H.W. 1970. Requirements, problems, and strategies: A theory of persuasion for social movements. Quarterly Journal of Speech, 56:1, 1-11.

Smith, A.L. [Asanti, M.K.]. 1969. Rhetoric of Black revolution. Boston: Allyn and Bacon.

Touraine, A. 1984/1988. The return of the actor: Social theory in postindustrial society. Forew. S. Aronowitz, trans. M. Godzivch. Minneapolis: University of Minnesota Press. 